\title{
The Qur'an and Inter-Religious Relation Models In Contemporary World
}

\author{
Kurdi Fadal \\ Institut Agama Islam Negeri (IAIN) Pekalongan, Indonesia \\ e-mail:kurdi_fadal@yahoo.com
}

\begin{abstract}
This article examines interreligious relations during the Qur'anic revelation and its contextualization in the contemporary world. This library research, focusing on 'Ali Jum'ah's thought, utilizes a qualitative with a historical approach. The results of this research show that the Qur'an was revealed in four models of Muslim and non-Muslim relations: the Meccan period model; the Habasyah phase, the first migration of some Muslims and as a minority under non-Muslims authority; and two Medina periods (the Early and the Latter) when Muslims become a majority who lived together peacefully with other religious communities under Muslim authority. Ali Jum'ah uses nasä' as a theory to contextualize the four models of interfaith relations. According to him, each of these models can be applied and developed in contemporary Muslims, especially in the Indonesian context, based on the principles of the Qur'an.
\end{abstract}

Keywords: Interreligious Relations; Qur'anic Principles; Contemporary Muslim.

\section{A. Introduction}

Interfaith relations between Muslims and other adherents of religions had taken place at the times of Qur'anic revelation, from the pre-hijra (in Mecca) to the post-hijra (in Medina) and continued from time to time. While Muslims developed as a majority group in certain countries, they became a minority in others. ${ }^{1}$ Peaceful relations have been developed in social diversity, but religious conflicts occasionally occurred in certain areas regardless of who was the majority or minority. Indonesia today is a good example to illustrate the dynamic relationship of interfaith because it has a majority Muslim population, but they are a minority in certain local counties such as Bali, Maluku, West Papua, and East Nusa Tenggara. Interfaith harmony became

${ }^{1}$ Naika Foroutan. "Identity and (Muslim) integration in Germany." Washington, DC: Migration Policy Institute (2013), h. 4. After World War II, Western countries had accepted a wave of Muslim immigrants and refugees from the Middle East and Africa. Shiri Relevy, Perspective of Otherness: Muslim in Europe between Assimilation and Polarisation, Jerusalem: European Forum at the Hebrew University, 2015, h. 4. 
Indonesian identity. However, the opposite condition has oftentimes occurred in several regions over the last few decades, such as discrimination, persecution, vigilantism, ${ }^{2}$ and other social conflicts involving interfaith communities.

Globally, Islam and the West have been facing a crisis of relations in recent decades. The attacks of September 11, 2001, have aggravated opinion of the international community about Islam. ${ }^{3}$ Some of the subsequent acts of terrorism in the name of Islamic doctrine further weaken Muslims' position in global relations. Consequently, Islamophobia increased strongly in the West, and anti-Muslim sentiment spread in Muslim-minority countries. ${ }^{4}$ Then, several issues arose such as Islamic extremism, Islamophobia, radicalism, extremism connected to Islam. The religious understanding of a few Muslims was considered as one of the reasons. They used 'polemic verses' as a basis in viewing other religions such as verses of warfares and superiority of Islam over other religions.

The Qur'an was revealed in the context of 14th centuries ago, but its universal messages should be implemented in the context of contemporary society. ${ }^{5}$ For this reason, Muslims should prove the concept of ummah in the Qur'an, as moderate community/ummah wasat (QS. Al-Baqarah [2]: 143) and as the best people/khair ummah (QS. 'Ali' Imrān [3]: 110). Thus, Muslim people should provide a 'role model' in building ukhuwah (brotherhood) based on the

${ }^{2}$ Ahnaf dan Hairus Salim, Krisis Keistimewaan (Yogyakarta: CRCS, 2017), h. 3-6

3 Doebler notes that the Eastern Europeans are more intolerant than the Western Stefanie Doebler, Relationships Between Religion and Intolerance Towards Muslims and Immigrants in Europe: A Multilevel Analysis, Rev Relig Res, 2014.

${ }^{4}$ Lihat Kaplan, J. Islamophobia in America?: September 11 and Islamophobic hate crime. Terrorism and Political Violence, 18(1), 2006, 1-33; Ernst, C. (Ed.). Islamophobia in America: The anatomy of intolerance. Springer, 2013; Love, E. Islamophobia and racism in America. NYU Press, 2017; Ogan, C., Willnat, L., Pennington, R., \& Bashir, M. The rise of antiMuslim prejudice: Media and Islamophobia in Europe and the United States. International Communication Gazette, 76(1), 2014, 27-46; Naika Foroutan. "Identity and (Muslim) Integration in Germany." Washington, DC: Migration Policy Institute (2013): 4, h. 1

5 Abdullah Saeed, Interpreting the Qur'an: Towards a Contemporary Approach (New York: Routledge, 2006), h. 134 
Qur'anic message and the 'uswah hasanah' of the Prophet SAW as guidelines of how to live, interact, understand, and cooperate with other religions people. ${ }^{6}$

This article discusses 'Ali Jum'ah's thought on the model of relations between religious believers at the time of the revelation of the al-Qur'an. This study by focusing on his works, al-Namāziij al-'Arba'ah, analyzes three points: First, the phase of the revelation of the verses of the Koran regarding the relations between religious believers. Second, the theory used by Ali Jum'ah in understanding these verses. Third, the contextualization of interfaith relationship verses in contemporary society. The historical approach in this study is used to analyze the models of relations during the revelation of the Qur'an.

\section{B. The viewpoint of Interreligious Relationship}

Religious diversity studies have been conducted by several researchers. Roger Boase, for instance, explained three models of people's views on diversity. First, diversity was perceived as a threat to religious beliefs. They wanted uniformity of their version of religious doctrine. Second, religious diversity was considered as God's grace which can inspire mutual understanding, sharing, and dialogue. Third, it was regarded as a cause of each adherent to deny the truth of religious teachings because of indoctrination with modern values. ${ }^{7}$ Studies on the Prophet's experience as a basis for developing interfaith relations in the contemporary world considerably referred to the Medina phase, such as Considine, ${ }^{8}$ Hilal Wani, ${ }^{9}$ and others..$^{10}$

${ }^{6}$ Mohd Yaseen Gada. "On Pluralism, Religious 'Other', and the Quran: a Post September-11 discourse." Indonesian Journal of Islam and Muslim Societies 6.2, 2016, 242.

7 Roger Boase. "Ecumenical Islam: A Muslim Response to Religious Pluralism." Islam and Global Dialogue. Routledge, 2016, 20.

${ }^{8}$ Craig Considine. "Religious Pluralism and Civic Rights in a "Muslim Nation": An Analysis of Prophet Muhammad's Covenants with Christians." Religions 7.2 (2016), 1; Blakemore, "Faith-based Diplomacy and Interfaith Dialogue." Brill Research Perspectives in Diplomacy and Foreign Policy, Vol. 3, No. 2 (2019): 1-124.

${ }^{9}$ Hilal Wani, Raihanah Abdullah, and Lee Chang. "An Islamic perspective in managing religious diversity." Religions, Vol. 6, No. 2 (2015).

${ }^{10}$ Ghozali, A. M., \& Zaeny, A. Implementation of Pluralism Values in Indonesia and Its Relevance to The Medina Charter. KALAM, 13(2), 2019, 191-216; Fajriah, N. Kerukunan Umat Beragama: Relevansi Pasal 25 Piagam Madinah Dan Pasal 29 Uud 1945. Substantia: 
The Muslim-majority country, such as Turkey, has ratified some regulations in rising harmony life in religious pluralism to ensure that all citizens obtain justice regardless of religion or ethnicity. ${ }^{11}$ In other countries, some Muslims have also manifested interfaith harmony, such as American Muslims who considered the Abrahamic religions (Islam, Judaism, and Christianity) as equally saviour religions and avoided a perception of Islam's superiority over others. Huwe saw they utilized the contextual approach (sabab al-nuzul) in understanding the Qur'anic verses. ${ }^{12}$

\section{Brief Biography of 'Ali Jum'ah}

'Ali Jum'ah is a charismatic Egyptian scholar, ${ }^{13}$ a moderate Muslim, and a Shafi'ian adherent of Islamic jurisprudence. He became one of the knowledgeable Muslim figures, productive writers, and mastered various fields of Islamic scholarship. The works he has written reached approximately forty thousand titles of books, articles, and others, ${ }^{14}$ including Al-Namāzijj alArba'ah as the main focus of this study.

His intellectuality has been widely recognized among Muslim scholars and his scholarly authority in the field of religious studies led him to become a Grand Egyptian Mufti from 2003 to 2013. His Islamic fatwas had impressed many people with his scientific competence. Not only had his

Jurnal Ilmu-Ilmu Ushuluddin, 21(2), 2019, 162-169; Jailani, Piagam Madinah: Landasan Filosofis Konstitusi Negara Demokratis. Al-Daulah: Jurnal Hukum dan Perundangan Islam, 6(2), 2016, 269-295; Islam, Peaceful Coexistence of Various Religious Groups in Islam. Journal of Islamic Thought and Civilization (JITC), 8(2), 2018, 183-203.

11 Osman Murat Deniz. "The Possibility of Religious Pluralism in Turkey at the Crossroad of the Traditional and Global Existences." Danubius 2.33 (2015), 13-15; Mohd Roslan Mohd Nor, Issa Khan, and Mohammad Elius. "Analysing the Conceptual Framework of Religious Freedom and Interreligious Relationship in Islam." Indonesian Journal of Islam and Muslim Societies, Vol. 8, No. 2, (2018): 309-334.

12 Justine Howe. "Interpreting the Qur'an in the US: Religious Pluralism, Tradition, and Context." Journal of Qur'anic Studies Vol. 18, No. 3 (2016), 34.

13 Usāmah al-Sayyid al-Azharī, Asānīd al-Mișriyyin (Kairo: Dār al-Faqīh, 2011), 539540.

14 The other books are al-Madkhal ilā Dirāsah al-Mażāhib al-Fiqhiyyah; al-Kalim alTayyib fì al-Fatāwā al-'Așriyyah; al-Naskh 'inda al-Ușūliyyīn; al-Kāmin fì al-Haḍārāt alIslāmiyyah; al-Nibrās fì Tásīir al-Qur'ān al-Karīm; al-Jihād fĩ al-Islām; al-Ṭarīq ilā al-Turās. Usāmah al-Sayyid al-Azharī, Asānīd al-Mișriyyīn, 552. 
acknowledgement been given by the Muslim community but also by nonMuslim as awarded an honorary doctorate from the University of Liverpool, England in 2011. However, a few Muslim scholars disagreed with the religious fatwas he had expressed. In Egypt and certain Middle Eastern countries, the scholars contradicted his thoughts. Abdullah Ramadan Musa was a Muslim figure who resisted him strongly. Musa noted about 1000 fallacies of Ali Jum'ah's fatwas. ${ }^{15}$

\section{D. 'Ali Jum'ah and Interreligious Relations during the Prophetic Period}

Ali Jum'ah proposed four phases of the Qur'anic revelation, particularly on interfaith relations. He also addresses the four phases as "models" ${ }^{16}$

\section{Muslims in the Mecca Phase}

As a new religion, Islam was introduced to the Pagans who controlled the Ka'bah and Mecca. For thirteen years, Muslims had become a minority group and often experienced oppression, persecution, and hostility from the opponents of Islam. The bad experiences had erased the brotherhood relations among them that had been running long before Qur'anic revelation. ${ }^{17}$ Just before Islam, they had lived in harmony and helped each other in the social life of economy, politics, and other fields. But, they neglected the brotherhood and social harmony after Quranic revelation. ${ }^{18}$

In facing their oppression, to Ali Jum'ah, ${ }^{19}$ the al-Qur'an ordered Muslims to be steadfast and patient (QS. Al-Hijr [15]: 94-96; Al-Nahl [16]: 127, and QS. Al-Muzzammil [73]: 10) and Muslims still consistently performed worship at the Masjid al-Haram. The Prophet was successful in introducing Islam by preaching bil hikmah, wisdom (QS. Al-Nahl [16]: 125), without any

15 'Abdullah Ramaḍān Mūsā, al-Radd 'alā al-Muftī Dr. 'Alī Jum'ah, (Mesir: al-Dār alNūrāniyyah li al-Turās wa al-Buhūs̀ al-'Ilmiyyah, 2012).

16 'Alī Jum'ah, al-Namāżij al-'Arba'ah (Mesir: Dār al-Fārūq, 2013), 7-8.

17 Ibn Kas̀īr, al-Sīrah al-Nabawiyyah, (Beirūt: Dār al-Ma'rifah, 1976), Vol. 2, 48.

18 'Alī Jum'ah, al-Namāżij al-'Arba'ah, 7-8

19 'Alī Jum'ah, al-Namāżij al-'Arba'ah, 12-14. 
taunt (QS. Al-An'ām [6]: 106-108). Occasionally, the Prophet (PBUH) also had dialogues with the polytheists, especially in the field of faith (QS. al-Kāfirūn).

Not only was he ordered his companions to be patient in facing the polytheists in Mecca but also instructed them to migrate or seek refuge in a safe land. Habasyah was the first journey of Muslim migration, before Medina. The Qur'an gave them a choice of migration whether to Habasyah or Medina (QS. Al-Nahl [16]: 41-42).20 Other verse also confirmed the promise of great rewards for those who were patient and emigrated (QS. al-Zumar [39]: 10).

\section{Muslims in the Habasyah (Ethiopia) Phase}

In Habasyah, the interaction between Muslims and the Christian native occupants took place in peace and harmony. The leader Najjasyi (Ashamah) was so famous a just leader to his all citizens that Prophet Muhammad considered the country was very conducive and peaceful for Muslims. The Prophet Muhammad Said:

"If you go to the land of Habasyah, there has been a large kingdom where no one gets injustice. It is the right country for you to be restful and free to live. ${ }^{21}$

According to Ali Jum'ah, Najjasyi welcomed Muslims seeking refuge in his country. They got fair treatment, a warrant of safety, and religious freedom. $.^{22} \mathrm{Al}-$ Tabarī said Najjasyi was famous for upholding justice because no citizen would be persecuted. ${ }^{23}$ There had been theological dialogue between Ja'far ibn Abi Talib and the King. The leader wanted to know more about the religious teachings of Muslim immigrants. Ja'far read the Surah Maryam which informed a lot about the Imran's family especially Maryam and Jesus ('Isa). ${ }^{24}$ After listening to the Surah, ${ }^{25}$ Najjasyi confirmed that there were

20 Al-Baiḍāwī, Anwār al-Tanzīl wa Asrār al-Ta'wīl, (Beirūt: Dār Ihyā' al-Turās al'Arabiy, 1418 H), Vol. 3, 227

${ }^{21}$ Al-Bayhaqī, Sunan al-Kubrā, Vol. 9 (Beirūt: Dār al-Kutub al-'Ilmiyyah, 2003), 9.

22 'Alī Jum'ah, al-Namāżij al-'Arba'ah, 16.

${ }^{23}$ Al-Ṭabarī, Jāmi' a-Bayān, Vol. 13 (Beirūt: Muassasah al-Risālah, 2000), 540.

${ }^{24}$ Ibn Kasir, al-Bidāyah wa al-Nihāyah, Vol. 3 (Beirūt: Dār Ihyā' al-Turāṡ al-'Arabiy, 1988), 93-94.

${ }^{25}$ Al-Zamahsyarī, al-Kasysyāf, Vol. 1 (Beirūt: Dār a-Kitāb al-'Arabī, 1407 H), 669. 
similar teachings to the Christian teachings he believed in. He convinced that the Qur'an and the Bible came from the same source. ${ }^{26}$ On that occasion, it was also reported that the king shed tears after hearing the truth. His impression was emphasized in QS. Al-Maidah [5]: 83.

Muslims established harmony, peace, social collaboration with the Christian citizens, and respect each other in polite language. ${ }^{27}$ They had also fought in the ranks of native inhabitants. ${ }^{28}$ Ummu Salamah narrated her experience in Habasyah:

"When we were in Habasyah, we were good neighbors with the Habasyah residents. We were so safe in our religion that we worship Allah without disturbance and never heard any of what we did not like."29

The brotherhood between Muslims and Ethiopian Christians was preserved in the Medina phase by bilateral relation when the Prophet instituted the State of Medina, such as Najjasyi's expressions of congratulations and happiness for the Muslims' victory in the battle of Badr. ${ }^{30}$ The kindness, intimacy, and brotherhood between Muslims and the leader of Habasyah were mentioned in the QS. Al-Ma'idah [5]: 82.

\section{Muslims at The Early Medina Phase}

This phase focused on encouraging brotherhood (ukhuwwah) within Muslims: between the Muhajirin and the Ansar; Muslims and Jews; and among tribes of the Ansar (Aus and Khazraj). The Prophet Muhammad implemented two strategies to execute the effort. The first was to build a mosque which became not only a place of worship but also a medium to strengthen the brotherhood of Muslims (ukhuwwah Islamiyah). Ali Jum'ah argues that the mosque became a place in which Muslims discussed and resolved several

26 Al-Rāzī, Mafātīh al-Ghayb, Vol. 12, h. 414; Al-Zamahsyarī, Al-Kasysyāf, Vol. 1 (Beirūt: Dār al-Kitāb al-'Arabī, 1407 H), 669.

27 'Alī Jum'ah, al-Namāżij al-'Arba'ah, 23.

${ }^{28}$ Al-Sarakhsī, al-Mabsūț, Vol. 10 (Beirūt: Dār al-Ma'rifah, 1993), 166.

${ }^{29}$ Lihat Ibnu Hisyām, al-Sīrah al-Nabawiyyah, Vol. 1, 334-338

${ }^{30}$ Alī Jum'ah, al-Namāżij al-'Arba'ah, 30; Al-Bayhaqī, Sunan al-Kubrā, Vol. 4, 238. 
problems. They also learned religion, morals, and life systems from the main figure, Muhammad (PBUH). ${ }^{31}$

The second was to constitute the Medina Charter to unit brotherhood and citizenships among religious believers (Islam, Judaism, and the polytheists) and tribes (Aus, Khazraj, Najjār, ${ }^{32}$ 'Auf, Ṡa'labah, and Nadir). Ali Jum'ah perceived the Charter as the first document in the world intended to support brotherhood and coexistence in peace and justice for all citizens under Muhammad's leadership. ${ }^{33}$ However, few Jews eventually denied the Charter as their rejection from the Islamic authority. They betrayed the agreement and spread important information on the Medina-internal affairs to the enemies of Islam (QS. Al-Hashr [59]: 2). They collaborated with the Meccan polytheists to attack and fight against Muslims. In facing the threat, Muslims prepared defensive steps and welcomed the resistance (QS. Al-Maidah [5]: 82 and AlAhzab [33]: 26), but negotiation of peace was the principal procedure. ${ }^{34} \mathrm{War}$ was the last option if peace negotiation failed to reach.

Besides the Jews' hostility, Muslims in the Medina-early phase faced the hypocrites (munafiqūn) who displayed a faith outwardly but opposed inwardly to Islam. The prominent figure of the hypocrites was Abdullah ibn Ubay ibn Salūl. 35 Their conducts were far more hurtful than the Jews who were openly hostile to Islam, attending to the Prophet's assemblies, joining with the believers, and participating with believers in worship. A verse mentioned the hypocrites as mużabżabīn, who were neither believers nor disbelievers, addressed in the Quran at a special chapter, al-Munāfiqūn, revealed in the Medina phase. To grapple them, the Prophet took very careful actions to safeguard the Medina-social circumstance, so he never spread their names and did not show suspicious attitudes, even though he knew their identity from revelation (QS. Al-Taubah [9]: 49; Muhammad [47]: 16) until they died and

31 'Alī Jum'ah, al-Namāżij al-'Arba'ah, 32-33.

32 Bani Najjar was the tribe of the Muhammad's grandmother (Abd al-Muttalib's wife) and it was a transit area for the Prophet during his hijrah journey from Mecca to Medina. Ibnu Hibbān, al-Sirah al-Nabawiyyah wa Akhbar al-Kulafa', Vol. 1 (Beirut: al-Kutub al-Saqafiyah, $1417 \mathrm{H}), 141$.

33 'Alī Jum'ah, al-Namāżij al-'Arba'ah, 37.

${ }^{34}$ Ibnu 'Asyūr, al-Tahrīr wa al-Tanwīr, Vol. 21, 312.

35 Al-Rāzī, Mafātīh al-Ghayb, Vol. 8, 345. 
buried outside the funeral of the believers. In addition, Muslims also interacted with the Medinan polytheists in this phase. Some of the Medina people still held their polytheism when the Prophet governed the city. However, their group was so minor that the Muslims' interaction with them did not socially impact. ${ }^{36}$

\section{Muslims in the Medina-Latter Phase}

Medina remained a plural city in religion in the later phase. Some Jews and other religious people still kept to their inherited religions. They were even the Muslims' closer neighbours. Until the Prophet passed away, they were mingled in social interactions with Muslims in peace. ${ }^{37}$ The Prophet provided them with justice and equality. (QS. Al-Nisa '[4]: 105, 135). However, some other residents of Medina (especially the hypocrites and the apostates) were still hostile to Muslims and spread slander to Islam (QS. 'Ali Imrān [3]: 72). The Prophet applied human values to them: not giving them any punishment as long as that hatred did not transcend limits, stamping them as "the blind hearts." Fighting against the apostates was not because of their apostasy but of their hostility, betrayal, and crime. ${ }^{38}$

Furthermore, the interaction between the Prophet Muhammad and other religious communities outside Medina had resulted in various peace agreements such as the Hudaibiyah Agreement (with the polytheists of Mecca), the Najran Agreement (with the Najran Christians, 631 AD). While other interactions ended in conquests such as the conquest of Khaibar (7th year) and Mecca lands (8th year) because of their hostility and betrayal to reconciliation, not to revenge for their previous persecution (in the Mecca phase). ${ }^{39}$ Thus, Islamic warfares were not to enforce Islamic religion to others but to resist those who betrayed the previous peace treaties (QS. Al-Anfäl [8]: 58).

\section{E. Theory of Nasā': Contextual Understanding of the Qur'an}

To understand the Qur'anic verses on the interfaith relationship, Ali Jum'ah utilized a theory of nasā, which meant that there was no any abrogation

\footnotetext{
36 'Alī Jum'ah, al-Namāżij al-'Arba'ah, 66, 76

37 'Alī Jum'ah, al-Namāżij al-'Arba'ah, 66-68.

38 'Alī Jum'ah, al-Namāżij al-'Arba'ah, 73-78.

39 'Alī Jum'ah, al-Namāżij al-'Arba'ah, 91.
} 
(nasakh) of such verse. So, every verse on interreligious relations should be a guideline in line of the current conditions of the Muslim community because each provides a different interest (maslahah) based on the progress of society.40 Some scholars said, one of the forms of nasakh was what the Qur'an asserted as a command for a certain reason and it had been abrogated for missing reason. It was not a form of naskh but nasă', ${ }^{41}$ or al-munsa' in Suyūṭi's term. ${ }^{42}$

The interaction among interfaith throughout the Qur'anic revelation had been running dynamically. A harmonious relationship was habitually established among adherents of religions but disputes and wars frequently occurred. The dynamic interaction had continually been guided by God's revelation. Some verses instructed Muslims in the Mecca period to be patient without resistance and fighting even though they were under pressure and persecution (QS. Hūd [11]: 11, 115; al-Anfāl [8]: 66; 'Ali Imrān [3] ]: 186). On the contrary, other verses at the Medina phase instructed the believers to jihad (QS. Al-Anfāl [8]: 39, 65; Al-Baqarah [2]: 193). Besides, various verses affirm a positive impression towards certain religious followers, such as QS. Al-Baqarah [2]: 109, 120; Nisā '[4]: 86, while other verses address other different groups in negative characters (QS. Ali 'Imrān [3]: 70-71; al-Māidah [5]: 51; 57), critical expression (QS. Ali 'Imran [3]: 65; al-Nisa '[4]: 171), or positive statement for Christians but a negative expression for Jews and polytheists (QS. Al-Maidah [5]: 82). Based on the nasä' theory, the above contradictory verses must be understood and applied for its particular context without any abrogation. These dynamics were part of the history of Muslims' interactions with other religious communities in the four phases along with the direct guidance response from revelation.

Ali Jum'ah discussed that every verse of jihad was categorized as muhkam which was not abrogated so it was an obligation for Muslims for all times. Jihad, in other words, was an everlasting duty for every Muslim. To

40 'Alī Jum'ah, al-Namāżij al-'Arba'ah, 138.

41 'Alī Jum'ah, al-Namāżij al-'Arba'ah, 139.

42 Al-Suyūțī, al-Itqān fì 'Ulūm al-Qur'ān, Vol. 3 (Mesir: Al-Hai'ah al-Mișriyyah al‘Āmmah, 1974), 68. 
interpret the jihad verses, Ali Jum'ah provided two notes. ${ }^{43}$ First, jihad in the Quran did not constantly refer to warfare or fighting which was one of its meanings (QS. Al-Baqarah [2]: 190-194; al-Anfāl [8]: 39; al-Taubah [9]: 29, 36, 73, 123; al-Tahrim [66]: 9). Meanwhile, the other meanings of jihad were asserted in several verses such as QS. Al-Hājj [22]: 78; al-'Ankabūt [29]: 69. The information of the Prophet's hadith also showed the various meanings of jihad, i.e, fighting against lust, carrying out "amr ma'rūf-nahy munkar". It was emphasized that fighting against the opponent was a minor jihad, while jihad against lust was a big one. Ali Jum'ah, gave an argument that jihad of war only took place in times of war which was rarely experienced and jihad against lust applied to everyone throughout his life. ${ }^{44}$ Second, the jihad of war ordered in the Qur'an was a defensive step to protect the soul, to fight oppression, and to combat injustice. A verse asserts that striving in the path of God was an act of resistance (QS. Al-Hājj [22]: 39). According to Ali Jum'ah, the order of jihad in the Qur'an and hadith utilized general expression but referred to specific objects, particularly to people who were hostile and despotic towards believers. Warfare in the prophetic times took place for the disbelievers' hostilities and persecutions against Islam and the Muslims, not for their rejection of the Islamic teaching. As such, the order of jihad which means warfare in the history of Islam cannot be used as an excuse to fight against other communities or to impose religion on other people. Similar to the jihad verses, command on being patient, doing good deeds, and living in peace with other religious people cannot be ignored in social interaction. That was why Ali Jum'ah criticized some commentaries who examined that the jihad verses abrogate the verse about patience and peace. ${ }^{45}$

\section{F. Qur'anic Principles on Interfaith Relations}

The Quran emphasizes that Prophet Muhammad was sent to spread mercy to the world (QS. Al-Anbiyā '[21]: 107) and defined tolerance, freedom, peace, and justice as principles of interreligious life. According to Ali Jum'ah, these principles had been applied by the Prophet and his companions in a

43 'Alī Jum'ah, al-Namāżij al-'Arba'ah, 141-142.

44 'Alī Jum'ah, al-Nibrās fì Tafsīr al-Qur'ān al-Karīm, (Kairo: al-Wābil al-Ṣayyib li alIntāj wa Tauzī’ wa al-Nasyr, 2009). 128.

45 'Alī Jum'ah, al-Namāżij al-'Arba'ah, 139, 142. 
minority and majority life as these should also be guidelines for every Muslim community in each generation based on respective social contexts. ${ }^{46}$ By the principle of tolerance, all Muslims must face other communities with respective and honourable treatments. The Qur'an ordered Muslims to treat prisoners in a good and respectful manner (QS. Al-Insān [76]: 8), not to kill enemies who had surrendered; not to destroy houses, not to fight against those who close their doors and who enter the Masjidil Haram; and not to kill or persecute civilians from children, women and the elderly. 47

The second principle, freedom (hurriyyah), was also elaborated in the Qur'an (QS. Yūnus [10]: 99 and QS. Al-Baqarah [2]: 256) delivering the message that Islam was introduced politely and without compulsion: every person who would convert to Islam was openly welcomed and free of compulsion for those who were reluctant to convert to Islam (QS. Al-Kahfi [18]: 29; al-Qasasं [28]: 56.). The good relationship between the Prophet-Muslims and Najjasyi was sturdy evidence of how Islam appreciates the freedom of religion. This principle was also applied by Muslims in the Medina phase with their authority and political power (QS. Al-Baqarah [2]: 256). The Medina Charter emphasized textually this principle: the Jews did not force to join the Charter; they could determine choice respectively while getting freedom and protection as long as they did not commit an offence or crime and commit outside the limit; they also had the freedom to choose to live inside Medina or leave the land..$^{48}$ Religious freedom had also been manifested towards the Christian Najran when they visited Medina and worship at the Nabawi Mosque (QS. 'Āli 'Imrān [3]: 59). To Christians outside Medina, Islam was also politely preached without compulsion. Asserted in the Prophet's letter to the lord of Yemen:

"Jews or Christians who had converted to Islam are the faithful who have rights and obligations as others. However, anyone who sticks to the previous religion, Judaism and Christianity, will constantly be tolerated (no coercion)." 49

\footnotetext{
46 'Alī Jum'ah, al-Namāżij al-'Arba'ah, 6.

47 'Alī Jum'ah, al-Namāżij al-'Arba'ah, 132

${ }^{48}$ Ali Jum'ah, al-Namāżij al-'Arba'ah, 50.

${ }^{49}$ Ibnu Hisyām, al-Sïrah al-Nabawiyyah, Vol. 2, 589.
} 
The prophetic task was only to convey the teachings of revelation to other religious people (QS. Yāsīn [36]: 17) and invite them to embrace Islam without compulsion. It has been asserted in the Qur'anic verse that Islam gives freedom to the polytheists who want to hear verses or know the Qur'anic teachings and laws (QS. Al-Taubah [9]: 6) then they could choose either to accept Islam or reject it. If they accept Islam, the choice is considered good. But if they refuse it, the verse orders to tolerate and return them to a peaceful and secure residence because their safety should be guaranteed.50

The principle of 'brotherhood' (ukhuwwah) was mentioned in QS. AlHujurāt [49]: 10; Al-Māidah [5]: 48; Al-Hujurāt [49]: 13; al-Nisā' [4]: 1). When the Prophet Muhammad had just arrived in Medina, brotherhood was shown by respecting the traditionalized-fasting Ashura of the local people (Jewish). Verses in the Medina period also sent down on the prohibition of destroying other religious houses of worship as a form of interfaith brotherhood (QS. AlHājj [22]: 40). Together with the Christian king of Habasyah, the brotherhood (ukhuwwah) shown by the Prophet was proven by several forms of cooperation, as previously explained. In prophetic history, Christians were the closest community to Muslims (QS. Al-Māidah [5]: 82). Principle of Justice should also be upheld in social interactions as asserted in QS. Al-Nahl 90; alNisā' 58; 105; al-Shūrā [42]: 15; Al-Mumtahanah [60]: 8; Al-Māidah [5]: 2, 8. In the auspices of the Islamic state, the justice value became a primary principle for all citizens regardless of any skin colour, race, and religion. ${ }^{51}$

The principle of 'peace' as defined in QS. Al-Hujurāt [49]: 9; al-Nisā' [4]: 90; al-Anfāl [8]: 81) which ordered that Islam should be preached to uphold peace for all communities. The Medina Charter was intended to develop peace in the diversity of religion, ethnicity, and social class. The Prophet had implemented several agreements of peace (hudnah) among communities outside Medina such as Christians of Najran, Yemen (10 H/631 AD), The Hudaibiyah agreement (with the polytheists of Mecca who were very despotic to the Prophet and his companions during the Mecca phase). Ali Jum'ah said, there had been never a mention of any obligation to pay tribute (jizyah) in the clauses of peace agreement with the People of the Scriptures (Ahl al-Kitāb)

${ }^{50}$ Al-Qurțubī, al-Jāmi' li Ahkām al-Qur'ān, Vol. 8, 76.

51 'Alī Jum'ah, al-Namāżij al-'Arba'ah, 71. 
outside Medina. 52 Morover, sending delegacies to sovereigns of other religious communities was one of the Prophet's traditions either in the Arab world or other regions. ${ }^{53}$

Not only had peace shown by actions but also peace by verbal words, i.e, remarks of salutation toward non-Muslims. Salām, which literally means peace, can also be conveyed to other religious people. It was not prohibited in Islam because of Qur'anic justification (QS. Al-Zukhruf [43]: 89, Al-Qașaș [28]: 55; Al-Furqān: 63). 'Ali Jum'ah emphasized that the Companions never find the Prophet speaking to other religious people except replying to them in a nice response. "Greeting" for non-Muslims had become controversial among scholars. Some assumed it was prohibited in Islam, but others considered it permissible. Both views were referred to the Sunnah which textually prohibited passing "greetings" to non-Muslim, but its context was specifically addressed to the Jews of the Quraidzah tribe. ${ }^{54}$

\section{G. Reinventing Model of Interreligious Relations in Contemporary Indonesia}

Utilizing the theory of nasä', Ali Jum'ah underlined that Quranic verses responding to the interfaith experiences during prophetic times should become normative guidance for contemporary Muslims. ${ }^{55}$ Each of the four interfaith relation models described above should equally be applied and duplicated in the context of either minority or minority. Some verses can become a reference to build interfaith brotherhood in certain contexts. The other could also be a guide for different specific conditions. ${ }^{56}$ Each model can become an alternative model to develop relationships in the present and the future eras, not only their experiences in the Medina phases but also in Mecca and Habasyah. 57

\footnotetext{
52 'Alī Jum'ah, al-Namāżij al-'Arba'ah, 96.

53 Ibnu Hisyām, al-Sïrah al-Nabawiyyah, Vol. 2, 607.

54 'Alī Jum'ah, al-Namāżij al-'Arba'ah, 62.

55 'Alī Jum'ah, al-Namāżij al-'Arba'ah, 136.

56 'Alī Jum'ah, al-Namāżij al-'Arba'ah, 6.

57 'Alī Jum'ah, al-Namāżij al-'Arba'ah, 31.
} 
However, social changes and developments required further innovation for every Muslim to find the most suitable model. One model or combination of the models could be a consideration for Muslims in any place and time. ${ }^{58} \mathrm{As}$ Majority residents, Indonesian Muslims should become role models in organizing unity in diversity just like Muslims at the time of Medina in which the Medina Charter become their document. Yet, the Habasyian Muslims' experience can also be an alternative model for those who resided in a minority-Muslim area. What some American Muslims walked can be reproduced. ${ }^{59}$ Of course, the principles of peace, brotherhood, justice, tolerance, and freedom described in the Qur'an had to be implemented in social interactions among local citizens in a country and the world's inhabitants.

What Ali Jum'ah proposed required a comprehensive understanding of the prophetic history and also the social situations in which the Prophet dealt with during the revelation of the Qur'an. Only observing warfare history during the time of the prophetic times would reduce the substance of Islamic teachings. Such a misleading view could harm Islam and disrupt human civilization that impacted the notion of radicalism and violence in the name of religion. The Quran has ordered Muslims to enforce peace and keep away hostility in social diversity of religion, ethnicity, or colour. The description above evidenced that commanding good (amr ma'rüf) was without coercion or prohibiting evil (nahy munkar) was without violence, which should be performed by Muslims in Indonesia and over the world, as a majority or minority.

According to Ali Jum'ah, the Medina Charter was the prophetic method (al-manhaj al-nabawi) for religious diversity. Accordingly, it was a document of guidance not only for Muslims at the time of Quranic revelation but also for the subsequent Muslim generations. Affirmed by the principles of insāniyyah (humanity) and muwātanah (citizenship), it became a remarkable achievement for Islam and human civilization. 'Humanity' portrayed various elements of religion, ethnicity, color, or any other difference and 'citizenship' presented a guide for all citizens and communities to help and accommodate

\footnotetext{
58 'Alī Jum'ah, al-Namāżij al-'Arba'ah, 6, 134.

${ }^{59}$ Justine Howe. "Interpreting the Qur'an in the US: Religious Pluralism, Tradition, and Context." Journal of Qur'anic Studies Vol. 18, No. 3 (2016).
} 
each other based on the principles of brotherhood, equality, justice, and peace. ${ }^{60}$

The muwātanah (citizenship) principle found its stand in contemporary Indonesia. ${ }^{61}$ Pancasila, as a basic ideology of Indonesia, united all citizens. No citizen can feel more dominant than others. Every citizen had the same constitutional rights and got protection before the laws, including in implementing worship and teachings of respective religions, just like Muslims and Jews listed in the Medina Charter. Indeed, Indonesia has been implementing one model or step in keeping diversity and developing brotherhood for all citizens within the Unitary State of the Republic of Indonesia (NKRI). As such, Indonesian Muslims should be a role model in upholding peace and brotherhood between religions for being a miniature of world peace. ${ }^{62}$

The heyday of Islam in the Medina phase conveyed a message that Islam should politically be strong because Islamic teachings would be much easier to implement in society with political power, including how to develop relationships with people of other religions based on the Qur'anic missions. Muslims must naturally be proud of the achievement of the previous Islamic civilizations. Nevertheless, there should be no glorification of the achievements notably on how Muslims won many warfares against other communities. The glorification of the golden age of Islam in the past would merely be so trapped in a historical fantasy that contemporary Muslims tend to neglect the Quranic principles in getting in touch with other communities. However, religious sentiment has been spreading in Indonesia for recent decades. Few Indonesian Muslims become supporters of interreligious conflicts. ${ }^{63}$ As a majority, they consider themselves most entitled to rule Indonesia. Religious Identity politics has become a tool of propaganda to achieve power goals. Such an outlook tends

60 'Alī Jum'ah, al-Namāżij al-'Arba'ah, 48.

61 Muhamad Ali. "The Conceptions of Sharia and Citizenship in Indonesia and Malaysia." Journal of Asian Social Science Research 1.1, 2019: 1-14.

62 Syamsun Ni'am. "Pesantren: the Miniature of Moderate Islam in Indonesia." Indonesian Journal of Islam and Muslim Societies 5.1 (2015): 111-134.

63 Tery Setiawan, "The Relation between religiosity dimensions and support for interreligious conflict in Indonesia, " Archive for the Psychology of Religion 42.2 (2020): 244-261, 256. 
to deliver conflicts among Muslims which is ultimately a disadvantage to Islam itself. So, Islamic brotherhood among Muslims (ukhuwwah islämiyah) must first be strengthened before brotherhood with other religious people (ukhuwwah insāniyah). Turkey's experience in building religious peace could be probably a suitable pattern for Indonesian Muslims.

No discrimination or persecution was justified or permitted in religion. So, every citizen of six official religions in Indonesia should mutually establish nice relations with each other in actions or words (greetings, etc.). Any inferior narrative that tends to offend others should be avoided in daily life, such as calling "kafir" to other religious people. The Prophet never used such a narrative in the document of Medina Charter and in his letters to other communities outside Medina. That was a form of implementation of brotherhood and peace principles. ${ }^{64}$

Another point to be conscious of by contemporary Muslims was that the system of Medina State was different from the nation-state system implemented in Indonesia today. The past system of "ummah" was dissimilar to the contemporary system of democracy. Medina citizens were directly led by the Prophet Muhammad who had authority as executive, legislative and judiciary leader at once. But in the nation-state system, a leader of the executive, legislative, and judiciary performed respective duties and functions.

Besides, interreligious dialogue can become an effective step to find a way of peace and to break stagnation or conflict in diversity. The common word among religions can be achieved by dialogue, ta'ālaw ilā kalimah sawā' (QS. 'Āli Imrān [3]: 64). The word sawa' meant a point of truth that was recognized by all communities, without any distinction. ${ }^{65} \mathrm{~A}$ verse (QS. Al-Nahl [16]: 125) revealed in Mecca period should still become a guideline for contemporary Muslims. It could not be abrogated with the verse of warfare. ${ }^{66}$ What the Prophet implemented with the Christian leader of Najrān (QS. Ali Imran [3]: 64.) should be patterns for Indonesian Muslims. In the global era,

64 Umar Faruq Thohir. "Reinterpretasi Status Minoritas Dzimmi di Tengah Mayoritas Muslim." Asy-Syari'ah: Jurnal Hukum Islam 6.2, 2020: 171-185.

65 Izzat Darwazah, al-Tafsīr al-Hadīs,Vol. 7, 148.

66 See al-Qurțubī, al-Jāmi' li Ahkām al-Qur'ān, Vol. 10 (Cairo: Dār al-Kutub alMișriyyah, 1964), 200 
everyone can easily perform a dialogue with others without limitation and boundary of territory or country. ${ }^{67}$

\section{H. Conclusion}

The interfaith relations during the revelation of the Qur'an, according to Ali Jum'ah, can be classified into four models: the Mecca, the Habasayah, and the two Medina phases (Early and Latter). Each model had distinctive characteristics: the Mecca and the Habasyah periods were the Muslimminority area, but each displayed contradictive experiences. While Muslims in the Mecca phase lived under pressure and persecution from the polytheists, they resided in Habasyah in peace and harmony with indigenous people who were predominantly Christian. In the Medina period, Muslims had power and political authority in which the Medina Charter became a unifying agreement to develop interfaith relations, even though some others were hostile to Islam.

Ali Jum'ah utilized the theory of nasā' to understand Quranic verses on interfaith relationships without abrogation. These should become normative guidelines and be implemented by contemporary Muslim generations based on Quranic principles. Each model of interfaith relations that took place during the Quranic revelation, as Ali Jum'ah explained, can be applied and duplicated in the context of contemporary Muslim life, either as a majority or a minority, including the Muslim's experience during the Habasyah phase. One of the models can be performed by Indonesian Muslims as a minority in certain areas. In specific situations, a combination of the relation models can be an option while still paying attention to the basic principles explained in the Qur'anic verses: tolerance, freedom, peace, and justice.

67 Gritt Klinkhammer. "Interreligious Dialogue Groups and the Mass Media." Religion, 2020: 1-17. 


\section{BIBLIOGRAPHY}

Ahnaf and Hairus Salim. Krisis Keistimewaan, Yogyakarta: CRCS, 2017.

Ali, Muhamad. "The Conceptions of Sharia and Citizenship in Indonesia and Malaysia." Journal of Asian Social Science Research 1.1 (2019): 1-14.

As̀īr, Ibn al-. al-Kāmil fi al-Tārīkh, Beirūt: Dār al-Kitāb al-'Arabī, 1997.

'Asyūr, Muhammad Țāhir Ibnu. al-Tahrīr wa al-Tanwīr, Tūnis, al-Dār alTūnisiyah li al-Nasyr, 1984.

Azharī, Usāmah al-Sayyid al-, Asānīd al-Mișriyyin, Kairo: Dār al-Faqīh, 2011.

Baiḍāwī, Anwār al-Tanzīl wa Asrār al-Ta'wīl, Beirūt: Dār Ihyā' al-Turās̉ al'Arabiy, $1418 \mathrm{H}$.

Bayhaqī, Sunan al-Kubrā, Beirūt: Dār al-Kutub al-'Ilmiyyah, 2003

Blakemore, "Faith-based Diplomacy and Interfaith Dialogue." Brill Research Perspectives in Diplomacy and Foreign Policy, Vol. 3, No. 2 (2019): 1124.

Boase, Roger. "Ecumenical Islam: A Muslim response to Religious Pluralism." Islam and Global Dialogue. Routledge, 2016.

Considine, Abdullah. "Religious Pluralism and Civic Rights in a "Muslim Nation": An Analysis of Prophet Muhammad's Covenants with Christians." Religions 7.2 (2016).

Darwazah, Muhammad Izzah al-Tafsìr al-Hadïs, Kairo: Dār Ihyā’ al-Kutub al'Arabiyyah, $1383 \mathrm{H}$.

Deniz, Osman Murat. "The Possibility of Religious Pluralism in Turkey at the Crossroad of the Traditional and Global Existences." Danubius 2.33, 2015.

Doebler, Stefanie. Relationships Between Religion and Intolerance Towards Muslims and Immigrants in Europe: A Multilevel Analysis, Rev Relig Res, 2014.

Ernst, C. (Ed.). Islamophobia in America: The anatomy of intolerance. Springer, 2013. 
Foroutan, Naika. "Identity and (Muslim) integration in Germany." Washington, DC: Migration Policy Institute, 2013.

Gada, Mohd Yaseen. "On Pluralism, Religious 'Other', and the Quran: a Post September-11 discourse." Indonesian Journal of Islam and Muslim Societies 6.2, 2016.

Hibbān, Ibnu, al-Sirah al-Nabawiyyah wa Akhbār al-Kulafā', Beirut: al-Kutub alSaqafiyah, $1417 \mathrm{H}$.

Hisyām, Ibn. al-Sirah al-Nabawiyyah, Mesir, Syirkah Maktabah Mațba'ah Muștāfāa al-Bābī al-Halabī, 1955.

Howe, Justine. "Interpreting the Qur'an in the US: Religious Pluralism, Tradition, and Context." Journal of Qur'anic Studies Vol. 18, No. 3, 2016.

Jum'ah, 'Alī, al-Namāżij al-'Arba'ah, Mesir: Dār al-Fārūq, 2013.

Jum'ah, 'Alī, al-Nibrās fi Tafsìr al-Qur'ān al-Karīm, Kairo: al-Wābil al-Ṣayyib li alIntāj wa Tauzī' wa al-Nasyr, 2009.

Kaplan, Jeffery. Islamophobia in America?: September 11 and Islamophobic hate crime. Terrorism and Political Violence, 18(1), 2006, 1-33;

Kas̀īr, Ibn. al-Bidāyah wa al-Nihāyah, Beirūt: Dār Ihyā' al-Turās̀ al-'Arabiy, 1988.

Kasīir, Ibn. al-Sirrah al-Nabawiyyah, Beirūt: Dār al-Ma'rifah, 1976.

Klinkhammer, Gritt. "Interreligious Dialogue Groups and the Mass Media." Religion (2020): 1-17.

Love, E. Islamophobia and Racism in America. NYU Press, 2017.

Mūsā, Abdullah Ramaḍān, al-Radd 'alā al-Muftī Dr. 'Alī Jum'ah, Mesir: al-Dār alNūrāniyyah li al-Turāś wa al-Buhūś al-'Ilmiyyah, 2012.

Ni'am, Syamsun. "Pesantren: the Miniature of Moderate Islam in Indonesia." Indonesian Journal of Islam and Muslim Societies 5.1, 2015: 111-134.

Ogan, C., Willnat, L., Pennington, R., \& Bashir, M. The rise of anti-Muslim prejudice: Media and Islamophobia in Europe and the United States. International Communication Gazette, 76(1), 2014, 27-46

Qurțubī, al-Jāmi' li Ahkām al-Qur'ān, Cairo: Dār al-Kutub al-Mișriyyah, 1964. 
Relevy, Shiri. Perspective of Otherness: Muslim in Europe between Assimilation and Polarisation, Jerusalem: European Forum at the Hebrew University, 2015.

Roslan, Mohd, dkk. "Analysing the Conceptual Framework of Religious Freedom and Interreligious Relationship in Islam." Indonesian Journal of Islam and Muslim Societies, Vol. 8, No. 2, (2018): 309-334.

Saeed, Abdullah. Interpreting the Qur'an: Towards a Contemporary Approach, New York: Routledge, 2006.

Sarakhsī, al-Mabsūt, Beirūt: Dār al-Ma'rifah, 1993

Setiawan, Tery; dkk, "The Relation between religiosity dimensions and support for interreligious conflict in Indonesia, "Archive for the Psychology of Religion 42.2 (2020): 244-261.

Suyūṭī, Jalāl al-Dīn al-, al-Itqān fi 'Ulūm al-Qur'ān, Mesir: Al-Hai'ah al-Mișriyyah al-'Āmmah, 1974.

Ṭabarī, Ibn Jarīr. Jāmi' al-Bayān fi Ta'wīl Āy al-Qur'ān, Beirūt: Muassasah alRisālah, 2000.

Thohir, Umar Faruq. "Reinterpretasi Status Minoritas Dzimmi di Tengah Mayoritas Muslim." Asy-Syari'ah: Jurnal Hukum Islam 6.2 (2020): 171185.

Wani, Hilal, Raihanah Abdullah, and Lee Chang. "An Islamic perspective in managing religious diversity." Religions, Vol. 6, No. 2 (2015).

Zahabī, Syamsuddin al-, Tārīkh al-Islām. Beirūt: Dār al-Kitāb al-'Arabī, 1992.

Zamahsyarī, al-Kasysyāf, Beirūt: Dār a-Kitāb al-'Arabī, 1407 H.

Zarkasyi, al-Burhān fì 'Ulūm al-Qur'an, Beirūt: Dār Ihyā' al-Kutub al-'Arabiyyah, 1957. 
KuRdi FADAL: The QuR'An And InTER-RELIGIOUS RELATION MODELS... 